\title{
Soil seed banks of remnant and degraded Swartland Shale Renosterveld
}

\author{
Steffen Heelemann, Cornelia B. Krug, Karen J. Esler, Christoph Reisch \& Peter Poschlod
}

Keywords

Abandoned field; Cape Floristic Region;

Degradation; Fynbos; Soil seed bank

\begin{abstract}
Abbreviations
CFR = Cape Floristic Region; TNR = Tygerberg

Nature Reserve; RV1, RV2, RV3 = renosterveld

sites; AF1, AF2 = abandoned fields; $P P=$ pine

plantation; $P C=$ pine clear-cut; $D C A=$

detrended correspondence analysis

$\mathrm{NGO}=$ non-governmental organization
\end{abstract}

Nomenclature

Goldblatt \& Manning (2000)

Received 6 April 2012

Accepted 20 December 2012

Co-ordinating Editor: Ladislav Mucina

Heelemann, S. (corresponding author, steffen.heelemann@web.de), Reisch, c. (christoph.reisch@biologie. uni-regensburg.de) \& Poschlod, P.

(peter.poschlod@biologie.uni-regensburg.de): Institute of Botany, University of Regensburg, 93040, Regensburg, Germany

Krug, C.B. (cbkrug@gmail.com): Laboratoire d'Ecologie, Systématique et Evolution (ESE), CNRS UMR 8079, Université Paris-Sud 11, Orsay, France

Esler, K.J. (KJE@sun.ac.za): Department of Conservation Ecology and Entomology and Centre for Invasion Biology, Stellenbosch

University, Stellenbosch, 7602, South Africa

\begin{abstract}
Questions: What are the characteristics of soil seed banks in highly endangered renosterveld vegetation and adjacent degraded sites? What is the contribution of the soil seed bank to restoring renosterveld vegetation after degradation through agriculture or afforestation?
\end{abstract}

Location: Tygerberg Nature Reserve - one of the largest remaining fragments of Swartland Shale Renosterveld, Cape Floristic Region, South Africa.

Methods: Assessment of vegetation, soil parameters and soil seed banks in three renosterveld sites, two adjacent abandoned fields, one pine plantation and one pine plantation clear-cut site. Smoke primer (i.e. fire surrogate) was applied to soil seed bank samples to evaluate fire as a possible management and restoration tool.

Results: Abandoned agricultural fields adjacent to renosterveld remnants are characterized by alien grass cover, nutrient enrichment of the soil and depletion of the indigenous soil seed bank. In contrast, pine plantations show less alien species infestation, soil nutrient alteration and have a viable soil seed bank as well as re-development of indigenous renosterveld vegetation after clearance. Seedling recruitment was not significantly influenced by application of a smoke primer compared to the magnitude of fire response in fynbos.

Conclusion: Abandoned agricultural fields (previously renosterveld) at Tygerberg have a very low restoration potential. In contrast, pine plantation sites should be given priority in restoration, because soil chemistry is less significantly altered and a viable indigenous soil seed bank is still present, which can be successfully activated through clearance management.

\section{Introduction}

The Cape Floristic Region (CFR) at the south-western tip of Africa is the most species-rich region in the outer tropics and a biodiversity hotspot hosting nearly 9000 species, ca. $70 \%$ of them endemic (Myers et al. 2000). Fynbos, strandveld and renosterveld (Rebelo et al. 2006) are the main vegetation types. All three vegetation types, especially renosterveld, are threatened by transformation into arable land and viticulture, but also by urbanization and invasive species.

Whereas fynbos and strandveld occur on nutrientpoor soils, renosterveld is found on comparatively nutri- ent-rich soils. Here, large-scale habitat transformation, mainly for agricultural production, occurred with European settlement from 1652 (Kemper et al. 1999). A further reason for degradation of renosterveld is associated with pine plantations, as Pinus species are invasive (Kruger et al. 1989; Richardson et al. 1994), but the exact extent of invasion is unknown. Only ca. $8 \%$ of the former renosterveld extent remains, so that it is now one of the most endangered vegetation types in South Africa, occuring in small, frequently isolated fragments (von Hase et al. 2003; Rebelo et al. 2006). Abandonment of agricultural fields began in the 1980s, due political and policy changes (Newton \& Knight 2005) and 
today renosterveld remnants are often surrounded near such fields, which are areas dominated by non-indigenous species, mostly southern European arable weeds and pasture grasses. Although anthropogenically altered and degraded by exotic species, these fields also provide opportunities for restoration (Cramer \& Hobbs 2007). Where these features occur adjacent to remnant natural sites of conservation value, restoration efforts could increase remnant size and create buffer zones.

Until recently, restoration research has mainly focused on fynbos (e.g. Holmes \& Richardson 1999; Fourie 2008). In contrast, renosterveld has received less attention although it harbours not only one of the most species-rich flora of geophytes worldwide, but also one-third of the CFR endemic species (Rebelo et al. 2006). For restoration of arable fields in renosterveld, only one case study exists (Krug \& Krug 2007). For restoration after clear-cut of pine plantations, only suggestions (De Villiers et al. 2005) and observations (C. Boucher, pers. comm.) have been made. However, as for arable fields, studies exist for clear-cut of pine plantations in fynbos (Holmes et al. 2000; Holmes 2001). Approximately $1 \%$ of former renosterveld, comprising abandoned fields and pine plantations (von Hase et al. 2003), provides potential restoration sites available to increase the extent of renosterveld (Krug \& Krug 2007) and to improve the flow of ecosystem goods and services (O'Farrell et al. 2009).

Restoration success is challenged by abiotic and biotic factors (Saunders et al. 1991), as well as temporal and spatial dispersal of seeds (Poschlod et al. 1998). One way to overcome these problems is to activate the 'memory' of pre-transformed vegetation, which could still be present as viable soil seed banks (Bakker et al. 1996). While soil seed banks of old fields and adjacent native vegetation have received some attention in fire-prone, Mediterranean biomes (Cramer \& Hobbs 2007), studies on renosterveld are rare, and no data are available on renosterveld soil seed banks under pine plantations in the Cape region. Previous studies have mainly concentrated on edge effects (Horn et al. 2011), while a small-scale seed bank study in mountain renosterveld showed low restoration potential of abandoned fields (Saayman $\delta$ Botha 2008). Both studies mentioned the problem of slow succession in abandoned fields. Experiments using sowing of early-successional species, as well as promoting seed dispersal by birds have been applied to abandoned fields, but were unsuccessful, despite their earlier reported potential (Heelemann et al. 2012). Similar problems arose in a pilot study after sowing and transplanting indigenous species in an abandoned vineyard (Holmes 2002b).

Although fire is used as an important management and restoration tool, studies have mainly focused on fynbos restoration after Acacia spp. and Pinus spp. invasion (e.g. Holmes et al. 2000; van Wilgen 2009). Fire has also been studied in renosterveld (Musil et al. 2005; H.R. Memiaghe \& D. Midoko-Iponga, unpubl. data), however the potential to stimulate the soil seed bank is unknown. Fire enhances germination indirectly through smoke extracts (De Lange E Boucher 1990; Brown 1993; Brown et al. 1993). Karrikinolide, a butenolide compound isolated from smoke, and cyanohydrins that release cyanide, were identified as active germination inducing substances (Flematti et al. 2004, 2011; Van Staden et al. 2004; Dixon et al. 2009). The extensive knowledge of post-fire restoration on degraded fynbos vegetation (Holmes 2002a; Holmes 2005 , 2008) therefore serves as a guideline and source of comparison.

In summary, it is common knowledge in the Cape region that ploughing destroys seed banks in abandoned fields and that pine plantations can preserve them; it is also known that fire can stimulate germination, but little information exists for threatened renosterveld. Therefore, the objectives of this study were to:

1. Analyse vegetation, soil parameters and soil seed bank of three renosterveld patches and adjacent degraded sites (i.e. two abandoned fields and one pine plantation).

2. Evaluate the effect of smoke primer (i.e. fire surrogate) on soil seed bank samples in a germination experiment to evaluate fire as a management and restoration tool.

3. Based on the data obtained, assess the effectiveness of pine plantation clearing as a restoration action.

\section{Methods}

\section{Study area and sites}

The study was performed at Tygerberg Nature Reserve (TNR) located north of Cape Town in the Cape Lowlands of South Africa $\left(33^{\circ} 52^{\prime} \mathrm{S}, 18^{\circ} 35^{\prime} \mathrm{E}\right.$ ) and containing one of the largest remaining fragments of Swartland Shale Renosterveld (hereafter renosterveld; Rebelo et al. 2006). The area has a typical mediterranean-type climate with a winter rainfall and summer drought regime. TNR receives up to $700 \mathrm{~mm}$ annual precipitation and mean monthly temperatures are between 24 and $11{ }^{\circ} \mathrm{C}$ (Lambrechts 1998). Records of European influence date back to 1655 when Jan Wintervogel first explored the Tygerberg area. Freehold farms with corn fields, vineyards, wheat, gardens, sheep and cattle farming were established in the 1700s. The area was partly farmed and ploughed until 1938, with cereals and grapes as the main farming products. Urban settlement took place from 1945 onwards (J. Kuyler, pers. comm.). Today TNR is an important conservation site, as well as an ecotourism and education centre. 
Randomly selected plots $(2 \mathrm{~m} \times 2 \mathrm{~m})$ in natural and degraded renosterveld were surveyed at TNR. Specifically, three renosterveld sites were examined (RV1, RV2, RV3; $3 \times 10$ plots). Adjacent to natural sites, degraded renosterveld sites were studied, namely abandoned fields (AFl, AF2; $2 \times 10$ plots) and a pine plantation (PP; 10 plots), both of which have had this status for many decades (J. Kuyler, pers. comm.). Environmental factors (e.g. slope, aspect, post-fire vegetation age) varied between all sites and mirrored the heterogeneity of renosterveld within a relatively small area of the TNR.

Low levels of replication across sites are an unavoidable characteristic of soil seed bank studies, due to the immense work load and logistics involved. However, this study aimed to provide a first insight into this ecosystem and not a broad generalization about renosterveld.

\section{Vegetation and soil survey}

Using the plant cover estimation method within plots (Braun-Blanquet 1964), each living plant was identified to species level with the help of various field guides and herbarium specimens of the Tygerberg Nature Reserve Herbarium. Species identification was carried out during flowering seasons (Jul-Oct 2007 and 2008). In the case of identification failure, genus, family or life form was noted.

Five soil samples per plot $(0-10 \mathrm{~cm}$ depth) were taken in Aug 2007 and pooled (ca. 200 g soil per plot). After drying and sieving (mesh size $200 \mu \mathrm{m}$ ), each soil sample was analysed for certain soil parameters $(\mathrm{pH}$, plant available phosphorus and potassium, sum of exchangeable cations, conductivity, total nitrogen and carbon) by BemLab Pty Ltd., Strand, South Africa (http://www.bemlab.co.za). One soil sample per plot was taken to analyse water-holding capacity (Schlichting \& Blume 1966).

\section{Soil seed bank sampling and germination experiment with and without smoke primer}

Soil seed bank sampling took place in Mar and Apr 2007, following the procedure in Bakker et al. (1996). At each plot where vegetation surveys were made, 20 replicate soil cores (4-cm diameter, 10-cm depth, surface area $12.6 \mathrm{~cm}^{2}$, volume $125.7 \mathrm{~cm}^{3}, 1200$ cores in total) were taken at random and divided in two subsamples of different depth $(0-5 \mathrm{~cm}, 5-10 \mathrm{~cm})$. The samples were put in paper bags, exposed to air for a week for drying and stored dry at room temperature until further use. Later, soil samples were sieved with water (mesh size $5 \mathrm{~mm}$ ) to increase the seed/soil ratio (Ter Heerdt et al. 1996; Baskin et al. 2000). After sieving, the samples were placed on a sterile cultivation substrate (sand plus white peat with clay) in plastic trays $(60 \mathrm{~cm} \times 40 \mathrm{~cm})$ and watered either without or with smoke primer (Kirstenbosch Instant Smoke Plus). The fraction larger than $5 \mathrm{~mm}$ was visually checked for remaining seeds and bulbs. The cultivation trays were constantly watered through a plaited glass fibre thread from a water basin underneath for 1 mo. After that, irrigation was manually carried out by a garden sprayer. Light and temperature regimes were 14-hr light at $22{ }^{\circ} \mathrm{C}$ and 10 -hr dark at $10{ }^{\circ} \mathrm{C}$ (Brown \& Botha 2004). Germination trials were conducted in a greenhouse of the Botanical Institute at the University of Regensburg. The seedling emergence method was chosen to obtain species composition and abundances (Ter Heerdt et al. 1996). Emergence of seedlings was recorded; seedlings were removed weekly and identified where possible with the help of field guides and herbarium material. Unknown seedlings were grown until identification was possible. In case of identification failure, the specimen was treated as a separate species, and genus, family or life form was noted.

\section{Restoration experiment}

A pine clear-cut operation, involving a cut, remove and burn treatment and carried out by the staff of TNR and the NGO Friends of the Tygerberg in 2008 was investigated. On 10 randomly selected $2 \mathrm{~m} \times 2 \mathrm{~m}$ plots both vegetation and soil parameter were surveyed in the pine clear-cut site using the same methods as described above. Then they were compared with obtained data of this study.

\section{Data analyses}

Statistical comparisons of collected vegetation, soil parameters and soil seed bank data with normal distribution and homogenous variances, were carried out via single factor ANova, post-hoc LSD test or pair-wise $t$-tests. Remaining non-parametric data were analysed using Mann-Whitney $U$ and Wilcoxon tests. All tests were computed with spss for Windows (v. 15.0; SPSS Inc., Chicago, IL, US). Furthermore, vegetation and soil data were analysed via a detrended correspondence analysis (DCA) using PC-ORD v. 4.0 (MjM Software Design, Gleneden Beach, OR, US) in order to identify abiotic parameters that may have influenced species composition. Vegetation data constituted the main matrix and soil chemistry was standardized to become the second matrix.

\section{Results}

\section{Vegetation and soil survey}

In above-ground vegetation, total species number and mean species number per plot differed widely between 
Table 1. Species and seed number in vegetation and soil seed bank at Tygerberg. Renosterveld (RV1, 2, 3), abandoned field (AF1, 2), pine plantation (PP). Means and SE of means are given. Significant differences of ANOvA analysis with LSD post-hoc test between sites $(n=10)$ are indicated with different letters. Soil horizon comparison was done via combined $t$-test.

\begin{tabular}{|c|c|c|c|c|c|c|}
\hline & $\mathrm{RV} 1$ & $\mathrm{RV} 2$ & RV3 & AF1 & AF2 & PP \\
\hline \multicolumn{7}{|l|}{ Vegetation } \\
\hline Total no. of species & 36 & 78 & 93 & 15 & 21 & 59 \\
\hline $\begin{array}{l}\text { Mean no. of species } \\
\text { per plot ** }\end{array}$ & $15.3 \pm 0.2^{b}$ & $25.9 \pm 0.6^{c}$ & $27.6 \pm 0.6^{c}$ & $7.8 \pm 0.2^{\mathrm{a}}$ & $8.3 \pm 0.3^{a}$ & $13.6 \pm 0.4^{b}$ \\
\hline \multicolumn{7}{|l|}{ Soil seed bank } \\
\hline \multicolumn{7}{|l|}{ Total no. of species } \\
\hline W & 37 & 50 & 40 & 32 & 37 & 39 \\
\hline$S$ & 39 & 55 & 55 & 32 & 43 & 43 \\
\hline \multicolumn{7}{|c|}{ Alien species infestation \% } \\
\hline W & 30 & 24 & 23 & 47 & 46 & 33 \\
\hline $\mathrm{S}$ & 31 & 29 & 27 & 53 & 39 & 33 \\
\hline \multicolumn{7}{|c|}{ Mean no. of species per sample $(0-10 \mathrm{~cm})$} \\
\hline$W^{* \star \star}$ & $19.7 \pm 0.76^{\mathrm{a}}$ & $18.0 \pm 1.67^{a}$ & $19.0 \pm 1.00^{\mathrm{a}}$ & $14.8 \pm 1.23^{b}$ & $15.2 \pm 1.36^{\mathrm{ab}}$ & $13.9 \pm 1.13^{b}$ \\
\hline$S^{\star \star \star}$ & $22.4 \pm 1.12^{\mathrm{a}}$ & $23.0 \pm 2.25^{\mathrm{a}}$ & $23.2 \pm 1.17^{\mathrm{a}}$ & $15.6 \pm 1.33^{b}$ & $17.6 \pm 1.34^{b}$ & $14.6 \pm 0.92^{b}$ \\
\hline C & n.s & n.s & * & n.s & n.s & n.s \\
\hline \multicolumn{7}{|l|}{ Total no. of seeds } \\
\hline W & 1962 & 621 & 872 & 904 & 1447 & 599 \\
\hline S & 2582 & 890 & 1496 & 882 & 1652 & 657 \\
\hline \multicolumn{7}{|c|}{ Total no. of seeds per $1 \mathrm{~m}^{2}$} \\
\hline$W^{\star \star \star}$ & $15634 \pm 1471^{c}$ & $4948 \pm 1398^{a}$ & $6948 \pm 795^{a}$ & $7203 \pm 953^{a}$ & $11530 \pm 1727^{b}$ & $4773 \pm 821^{a}$ \\
\hline$S^{* \star *}$ & $20574 \pm 2276^{c}$ & $7091 \pm 1424^{b}$ & $11928 \pm 976^{a}$ & $7028 \pm 1203^{b}$ & $13163 \pm 1695^{a}$ & $5235 \pm 921^{b}$ \\
\hline C & $\star \star \star$ & n.s & $\star \star \star$ & n.s & n.s & n.s \\
\hline \multicolumn{7}{|c|}{ Mean no. of seeds per $1 \mathrm{~m}^{2}(0-5 \mathrm{~cm})$} \\
\hline$W^{* \star \star}$ & $8383 \pm 871^{b c}$ & $3578 \pm 1092^{a}$ & $5219 \pm 796^{a}$ & $6191 \pm 934^{\mathrm{ab}}$ & $10016 \pm 1512^{c}$ & $4199 \pm 791^{a}$ \\
\hline$S^{\star \star \star}$ & $11649 \pm 1309^{b}$ & $5195 \pm 1247^{a}$ & $8796 \pm 1030^{b}$ & $5888 \pm 1100^{\mathrm{ab}}$ & $11378 \pm 1558^{b}$ & $4486 \pm 938^{a}$ \\
\hline C & 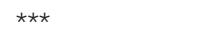 & n.s & $\star \star \star *$ & n.s & n.s & n.s \\
\hline \multicolumn{7}{|c|}{ Mean no. of seeds per $1 \mathrm{~m}^{2}(5-10 \mathrm{~cm})$} \\
\hline$W^{* \star \star}$ & $7251 \pm 770^{c}$ & $1371 \pm 361^{\mathrm{ab}}$ & $1729 \pm 336^{\mathrm{ab}}$ & $1012 \pm 232^{\mathrm{ab}}$ & $1514 \pm 351^{\mathrm{ab}}$ & $574 \pm 80^{a}$ \\
\hline$S^{* \star \star}$ & $8924 \pm 1179^{c}$ & $1896 \pm 378^{\mathrm{ab}}$ & $3132 \pm 410^{b}$ & $1139 \pm 223^{\mathrm{a}}$ & $1785 \pm 280^{\mathrm{ab}}$ & $749 \pm 77^{a}$ \\
\hline $\mathrm{C}$ & n.s & * & $\star \star$ & n.s & n.s & n.s \\
\hline \multicolumn{7}{|c|}{ Mean no. of seeds $(0-5 \mathrm{~cm}$ vs $5-10 \mathrm{~cm})$} \\
\hline W & n.s & ** & ** & $\star \star * *$ & $\star \star \star *$ & ** \\
\hline S & n.s & * & ** & 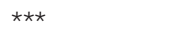 & $\star \star \star *$ & $\star \star$ \\
\hline \multicolumn{7}{|l|}{ Sørensen index } \\
\hline C & 0.81 & 0.51 & 0.51 & 0.52 & 0.49 & 0.69 \\
\hline
\end{tabular}

Significance level $\left({ }^{\star} P<0.05,{ }^{\star \star P}>0.01,{ }^{* \star \star} P<0.001\right)$. Sørensen index is given as similarity measure. Treatments: Without smoke primer (W), Smokeprimer treatment (S), Comparison (C).

sites (Table 1). With 15-21 species, abandoned fields had a lower total species number than pine plantation (59 spp.) and renosterveld (36-93 spp.). Significantly higher mean species numbers per plot were found in renosterveld 2 and 3 (25.9 spp., 27.8 spp.) compared to renosterveld l (15.3 spp.) and pine plantation (13.6 spp.). The lowest mean species number per plot was found in abandoned fields (7.88.3 spp.).

The DCA (Fig. 1) showed a distinct grouping of renosterveld communities (characterized by indigenous geophytes Oxalis purpurea and Zantedeschia aethiopica), and abandoned fields (characterized by alien grass species Avena barbata, Bromus pectinatus and Lolium multiflorum) at TNR. Alien grass species dominated the vegetation, with cover values often exceeding $50 \%$ per plot. The alien grass Briza maxima was mainly associated with the pine plantation that also was distinct from the other sites.

Results of the soil analysis show significant differences within and between renosterveld and degraded sites (Table 2). The strongest impact of degradation was visible in the significantly lower $\mathrm{pH}$ values under the pine plantation and elevated phosphorus levels in abandoned fields.

\section{Soil seed bank survey}

During the germination experiment without smoke primer, 6405 seedlings emerged from soil samples (Table 1). Total number of species and seeds varied, between 32-50 $\mathrm{spp} . \mathrm{m}^{-2}$ and $4948-15634$ seeds $\cdot \mathrm{m}^{-2}$ respectively, 


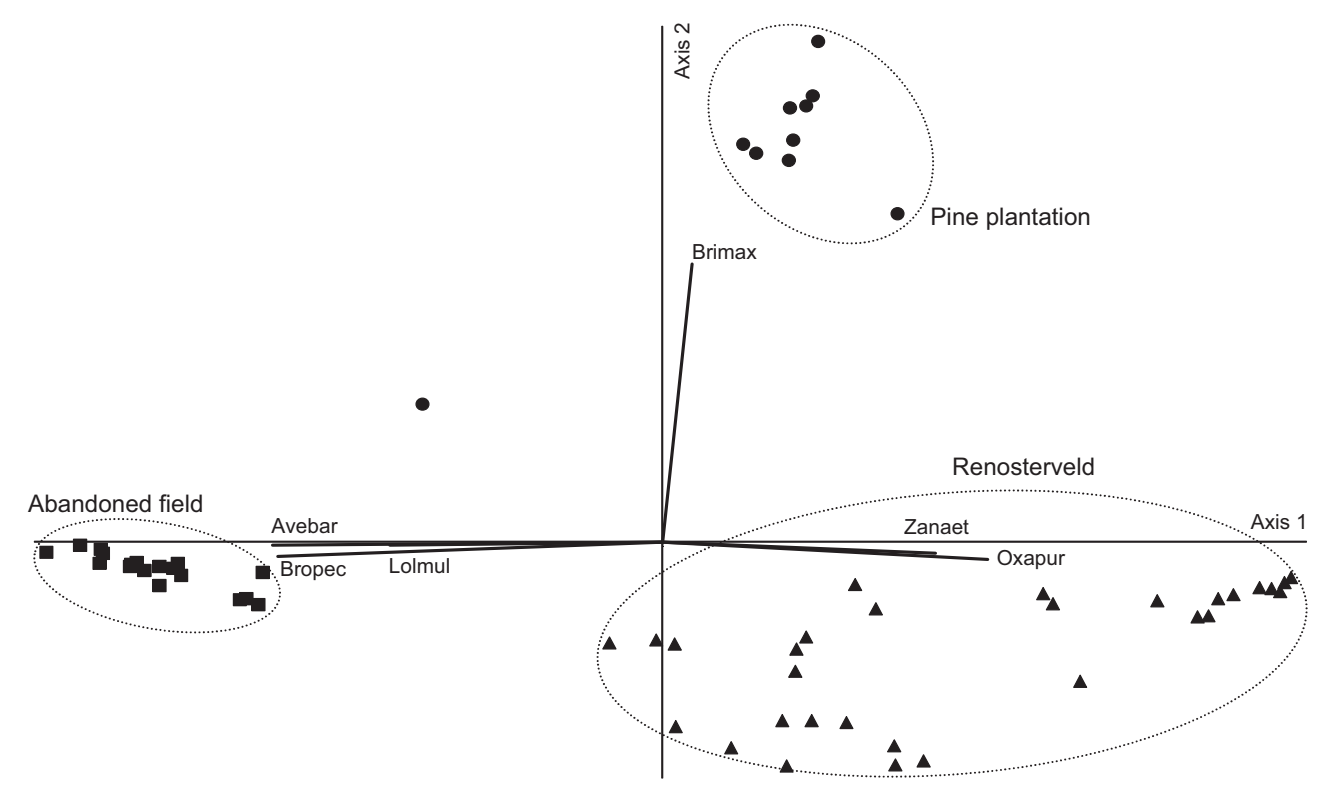

Fig. 1. DCA ordination of vegetation at Tygerberg Nature Reserve. Renosterveld (triangles), abandoned field (squares), pine plantation (circles), matrix: 169 species, 10 quadrats of six sites, increment (axis 1: 0.42, axis 2: 0.15), $r^{2}$ cut-off-value $=0.4$, species correlation axis 1: Avena barbata (Avebar, $r^{2}=0.63$ ), Bromus pectinatus (Bropec, $r^{2}=0.62$ ), Lolium multiflorum (Lolmul, $r^{2}=0.44$ ), Oxalis purpurea (Oxapur, $r^{2}=0.52$ ), Zantedeschia aethiopica (Zanaet, $\left.r^{2}=0.44\right)$, species correlation axis 2: Briza maxima (Brimax, $\left.r^{2}=0.48\right)$. Length of gradient: 4.73 .

Table 2. Comparison of soil parameters at Tygerberg. Mean, SE of mean and ANovA-analysis with LSD post-hoc test between sites $(* P<0.05$, $\left.{ }^{*} P<0.001\right)$ are given. Sampling sizes $(n=10)$, except for clay, silt and sand $(n=5)$. Cation exchange capacity (CEC) with $t$-value: sum of exchangeable sodium, potassium, calcium, magnesium and hydrogen. Conductivity (Cond.). Water-holding capacity (WHC). Significant differences of ANOVA analysis with LSD post-hoc test between sites $(n=10)$ are indicated with different letters.

\begin{tabular}{|c|c|c|c|c|c|c|}
\hline Parameter & RV1 & $\mathrm{RV} 2$ & RV3 & AF1 & AF2 & PP \\
\hline $\mathrm{pH}^{\star \star}$ & $5.5 \pm 0.1^{a}$ & $6.0 \pm 0.1^{b}$ & $5.4 \pm 0.1^{a}$ & $5.9 \pm 0.1^{b}$ & $6.2 \pm 0.1^{b}$ & $4.9 \pm 0.1^{c}$ \\
\hline $\mathrm{P}\left(\mathrm{mg} \cdot \mathrm{kg}^{-1}\right) \star \star$ & $11.1 \pm 1.6^{\mathrm{ab}}$ & $15.0 \pm 1.4^{b}$ & $5.5 \pm 0.5^{\mathrm{a}}$ & $27.8 \pm 3.4^{c}$ & $22.5 \pm 3.2^{c}$ & $8.4 \pm 0.4^{\mathrm{a}}$ \\
\hline $\mathrm{K}\left(\mathrm{mg} \cdot \mathrm{kg}^{-1}\right)^{\star \star}$ & $242.9 \pm 13.6^{\mathrm{a}}$ & $373.8 \pm 23.2^{c}$ & $259.4 \pm 14.3^{\mathrm{ab}}$ & $306.3 \pm 6.4^{b}$ & $295.7 \pm 31.6^{\mathrm{ab}}$ & $294.8 \pm 10.5^{\mathrm{ab}}$ \\
\hline$N_{\text {total }}(\%)^{* \star}$ & $0.22 \pm 0.01^{a}$ & $0.36 \pm 0.02^{b}$ & $0.19 \pm 0.01^{a}$ & $0.19 \pm 0.01^{a}$ & $0.19 \pm 0.02^{\mathrm{a}}$ & $0.35 \pm 0.03^{b}$ \\
\hline $\mathrm{C}_{\text {total }}(\%)^{\star}$ & $2.06 \pm 0.1^{b}$ & $1.89 \pm 0.1^{\mathrm{ab}}$ & $2.17 \pm 0.1^{b}$ & $1.97 \pm 0.1^{b}$ & $1.50 \pm 0.2^{\mathrm{a}}$ & $2.23 \pm 0.3^{b}$ \\
\hline $\mathrm{C}: \mathrm{N}^{\star \star}$ & $9.63 \pm 0.6^{c}$ & $5.42 \pm 0.4^{\mathrm{a}}$ & $11.40 \pm 0.4^{d}$ & $10.14 \pm 0.4^{c d}$ & $7.80 \pm 0.5^{b}$ & $6.22 \pm 0.4^{\mathrm{a}}$ \\
\hline $\mathrm{CEC}\left(\mathrm{cmol} \cdot \mathrm{kg}^{-1}\right)^{\star \star}$ & $10.5 \pm 0.5^{\mathrm{a}}$ & $16.1 \pm 1.4^{b}$ & $8.4 \pm 0.5^{a}$ & $10.4 \pm 0.3^{\mathrm{a}}$ & $9.6 \pm 0.9^{a}$ & $15.4 \pm 0.8^{b}$ \\
\hline Cond. $(\mathrm{Ohm})^{\star \star}$ & $1312 \pm 123^{b}$ & $1188 \pm 63^{\mathrm{ab}}$ & $1774 \pm 56^{c}$ & $1388 \pm 60^{b}$ & $1323 \pm 71^{b}$ & $1054 \pm 56^{a}$ \\
\hline WHC $(\%)^{\star \star}$ & $263.3 \pm 3.6^{b c}$ & $237.3 \pm 3.2^{\mathrm{a}}$ & $265.6 \pm 3.7^{c}$ & $247.9 \pm 5.0^{\mathrm{ab}}$ & $265.4 \pm 7.6^{c}$ & $239.2 \pm 7.8^{\mathrm{a}}$ \\
\hline
\end{tabular}

without a clear trend between renosterveld and degraded sites (Table 1). Site comparisons revealed significantly higher mean species number per plot in renosterveld $(18.0 \pm 1.0$ to $19.7 \pm 0.8)$ compared to degraded sites $(13.9 \pm 1.0$ to $15.2 \pm 1.4)$. Significantly higher seed densities occurred in the upper soil layer $(0-5 \mathrm{~cm})$ compared to the lower soil layer $(5-10 \mathrm{~cm})$, except for RV1. A high proportion of alien species was present in soil seed banks of abandoned fields (ca. 50\%), pine plantation and pristine renosterveld (ca. 30\%), irrespective of smoke-primer treatment.

With smoke-primer treatment, 8159 seedlings were encountered (Table 1). Smoke-primer treatment was fol- lowed by a significantly higher species number in RV3 and higher seedling numbers occurred in RV1, RV3 (total and upper soil layer), and for RV2, RV3 (lower soil layer). No significant effect could be detected for abandoned fields or pine plantation. Thirteen species, three of them alien, showed a significant increase in germination response after smoke-primer treatment (Table 3).

Both treatments are shown in Fig. 2, and reveal little difference between soil seed bank species composition after germination without and with smoke primer. Furthermore, vegetation of abandoned fields is more similar to seed banks than the vegetation of the renosterveld and pine plantation. DCA showed that the seed bank of reno- 
Table 3. Species with significantly increased germination response after smoke-primer treatment. Renosterveld (RV), abandoned field (AF), pine plantation (PP).

\begin{tabular}{|c|c|c|c|c|c|c|}
\hline & RV1 & $\mathrm{RV} 2$ & RV3 & AF1 & AF2 & PP \\
\hline \multicolumn{7}{|l|}{ Renosterveld species } \\
\hline Aspalathus flexuosa (Fabaceae) & P & $P$ & $P$ & - & $-2.5 *$ & - \\
\hline Conyza scabrida (Asteraceae) & $-2.6 *$ & P & P & $-2.0 *$ & - & $P$ \\
\hline Drosanthemum hispidum (Mesembryanthemaceae) & P & $-2.5^{*}$ & $-2.2^{*}$ & - & - & $P$ \\
\hline Helichrysum pandurifolium (Asteraceae) & $-2.2^{*}$ & P & $-2.1 *$ & $-2.2^{*}$ & $P$ & $\mathrm{P}$ \\
\hline Helichrysum teretifolium (Asteraceae) & P & $P$ & $-2.8 * *$ & $\mathrm{P}$ & $P$ & $P$ \\
\hline Isolepis marginata (Cyperaceae) & $-2.7 * \star$ & $P$ & $\mathrm{P}$ & $P$ & - & $\mathrm{P}$ \\
\hline Oxalis compressa (Oxalidaceae) & P & $P$ & $\mathrm{P}$ & $P$ & $-2.2^{*}$ & $-2.1 *$ \\
\hline Selago corymbosa (Scrophulariaceae) & $-2.1 *$ & - & P & - & - & - \\
\hline Senecio pubigerens (Asteraceae) & P & P & $-2.2^{*}$ & $P$ & $P$ & $P$ \\
\hline Sutera uncinata (Scrophulariaceae) & $P$ & $-2.4^{\star}$ & P & - & $P$ & $P$ \\
\hline \multicolumn{7}{|l|}{ Alien species } \\
\hline Anagallis arvensis (Primulaceae) & $P$ & $P$ & $P$ & P & $-2.2 *$ & $P$ \\
\hline Fumaria muralis (Papaveraceae) & $P$ & $P$ & $\mathrm{P}$ & $-2.1 *$ & $\mathrm{P}$ & - \\
\hline
\end{tabular}

Significant Z-values derived from Wilcoxon test ( $* P<0.05, * * P<0.01$ ) and shown in bold. Species present in soil seed bank, without significant smoke primer response $(\mathrm{P})$, species not present in soil seed bank (-).

Identified species that occurred only after smoke-primer treatment in low abundances with no statistical significance: Anisodentea biflora (Malvaceae), Antimima aristulata (Mesembryanthemaceae), Arcotheca calendula (Asteraceae), Carpobrotus sp. (Mesembryanthemaceae), Felicia dubia (Asteraceae), Hesperantha radiata (Iridaceae), Juncus capensis (Juncaceae), Oxalis purpurea (Oxalidaceae), Pinus radiata (Pineaceae), Plantago lanceolata (Plantaginaceae), Rhus laevigata (Anacardiaceae), Senecio scapiflorus (Asteraceae), Sutera hispida (Scrophulariaceae), Sutera sp. (Scrophulariaceae), Torilis arvensis (Apiaceae), Wahlenbergia sp. (Campanulaceae), Wahlenbergia capensis (Campanulaceae).

Unidentified species: geophyte 2, 3; herb 1, 4, 5, 6, 9, 12.

sterveld communities is mainly characterized by indigenous herb species, such as Helichrysum spp. (Fig. 2). Abandoned fields are characterized by the alien grass Lolium multiflorum. The pine plantation showed an intermediate position between abandoned fields and renosterveld sites.

\section{Restoration experiment}

The soil analysis of renosterveld, pine plantation and pine clear-cut showed statistically significant changes in all soil parameters, except carbon (Table 4). However, the majority of soil parameters did not differ between pine clearcut and renosterveld. Regarding above-ground vegetation, total and mean species number differed between sites. The lowest number of species, 59 (mean $13.8 \pm 0.4$ ), occurred at the pine plantation and was significantly lower than in renosterveld and pine clear-cut area. No significant difference was found between pine clearing (69 spp., $23.3 \pm 0.3$ ) and renosterveld (92 spp., $27.6 \pm 0.6$ ). Other indigenous species noted in the clear-cut area but not appearing within plots were Aristea africana (Iridaceae), Zantedeschia aethopica (Araceae), Gladiolus alatus (Iridaceae), Gladiolus watsonius (Iridaceae), Corycium orobanchiodes (Orchidaceae), Disperis villosa (Orchidaceae), Chrysanthemoides monilifera (Asteraceae) and Salvia africana-lutea (Lamiaceae). A few individuals of alien Pinus sp. and Acacia sp. appeared, possibly due to the absence of further clearing activities at the site.
The DCA analysis of vegetation and soil seed bank data (Fig. 3) showed a strong grouping that separated renosterveld, pine plantation, clear-cut site and the soil seed bank. Soil seed banks of near-natural renosterveld and pine plantation were not separated, indicating a similar species composition.

\section{Discussion}

In line with similar studies conducted in other mediterranean-type ecosystems (Cramer \& Hobbs 2007), our results reveal some of the underlying factors for the slow recovery of abandoned fields at the TNR, including dominance of competitive alien species, nutrient enrichment and a depleted indigenous soil seed bank. In contrast, the pine clear cut site showed less degradation; soil parameters were more similar to natural renosterveld communities and a viable indigenous soil seed bank existed.

\section{Vegetation and soil survey}

The vegetation analysis showed a clear separation and distinct species composition for renosterveld, abandoned fields and the pine clear-cut site. The species responsible for these differences were mainly alien grasses. The vegetation of the pine clear-cut site was more similar to renosterveld sites, which are characterized by indigenous shrubs and geophytes. Significantly higher species numbers were 


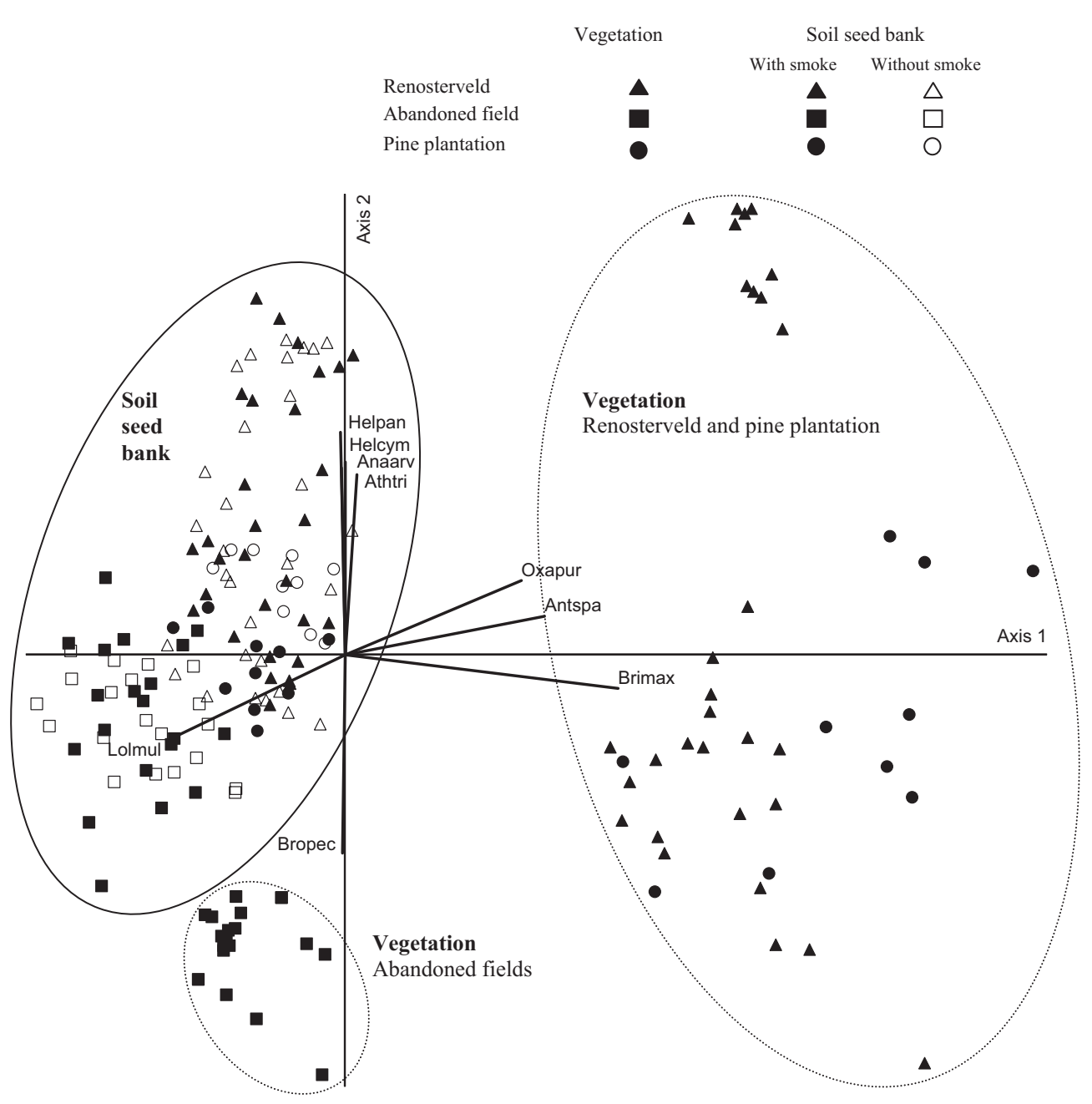

Fig. 2. DCA of vegetation and soil seed bank with and without smoke-primer treatment. Vegetation (dotted line), soil seed bank (full line) with/without smoke (dark/empty symbol). Renosterveld (triangles), pine plantation (circles), abandoned fields (squares). Power-transformed matrix of 232 taxa and 180 samples. Increment axis 1: 0.33, Axis 2: 0.23. Length of gradient: 4.1. $r^{2}$ cut-off: 0.35 . Species correlated with axis 1: Briza maxima ( $\left.r^{2}=0.55\right)$, Anthospermum spathulum $\left(r^{2}=0.40\right)$, Oxalis purpurea $\left(r^{2}=0.35\right)$, Lolium multiflorum $\left(r^{2}=0.36\right)$, species correlated with axis 2: Helichrysum pandurifolium ( $\left.r^{2}=0.45\right)$, Anagallis arvensis $\left(r^{2}=0.39\right)$, Helichrysum cymosum $\left(r^{2}=0.38\right)$, Athenisia trifurcata $\left(r^{2}=0.36\right)$, Bromus pectinatus $\left(r^{2}=0.41\right)$.

counted in natural habitats compared to degraded sites. Results indicate poor re-establishment of indigenous species in degraded habitats, even after a long period of rest, a phenomenon reported for other vegetation types (Eliason \& Allen 1997). Previous research on abandoned fields in renosterveld has shown that grass competition had a strong effect on establishment (Midoko-Iponga et al. 2005). Other barriers for establishment of native shrub species include root competition between alien and indigenous species (Davies 1985), high soil compaction of degraded habitats (Bassett et al. 2005) and the negative effect of herbivory (i.e. seed predation, seedling removal, trampling; Jones \& Esler 2004).

Comparison of renosterveld and degraded sites revealed many significant differences in soil parameters that indi- cate a strong impact of former agricultural activities (e.g. increased phosphorus level from fertilizer use) and forestry (e.g. acidification from pine litter). Elevated phosphorus levels on degraded land were also found in mountain renosterveld vegetation (O'Farrell \& Collard 2003), and elevated nitrogen levels promoted alien grass invasion in Western Cape Renosterveld fragments surrounded by wheat or vineyards (Sharma et al. 2010). In general, recovery of altered habitats is constrained by eutrophication problems (Bakker \& Berendse 1999). Nutrient enrichment is of special concern because it can enhance survival and invasion of alien species (Leishman \& Thomson 2005). In this context, abundant alien grasses are more effective competitors (i.e. nutrient uptake) compared to native shrubs (Caldwell et al. 1987; Suding et al. 2004). 
Table 4. Comparison of soil parameters, vegetation and soil seed bank in renosterveld and degraded sites. Means, SE of means, chi-square values of Kruskal-Wallis $H$-test and $P$-values ( ${ }^{*} P<0.05, * \star P<0.01, * \star \star P<0.001$, n.s. not significant) are given. Bold numbers show significantly different values from pine plantation (subsequent Mann-Witney U-tests including Bonferroni correction). Cation exchange capacity with $t$-value: sum of exchangeable sodium, potassium, calcium, magnesium and hydrogen (CEC). Sampling size $(n=10)$. Significant differences of ANOVA analysis with LSD post-hoc test between sites $(n=10)$ are indicated with different letters.

\begin{tabular}{|c|c|c|c|c|}
\hline & Pine plantation & Pine clearing & Renosterveld & Statistics \\
\hline \multicolumn{5}{|l|}{ Soil } \\
\hline $\mathrm{pH}$ & $4.88 \pm 0.07^{a}$ & $5.36 \pm 0.12^{b}$ & $5.41 \pm 0.07^{b}$ & $14.44^{\star \star}$ \\
\hline $\mathrm{P}\left(\mathrm{mg} \cdot \mathrm{kg}^{-1}\right)$ & $8.40 \pm 0.40^{a}$ & $5.60 \pm 1.81^{b}$ & $5.50 \pm 0.45^{\mathrm{b}}$ & $9.98^{* *}$ \\
\hline $\mathrm{K}\left(\mathrm{mg} \cdot \mathrm{kg}^{-1}\right)$ & $294.8 \pm 10.52^{a}$ & $237.0 \pm 19.26^{b}$ & $259.4 \pm 14.28^{\mathrm{ab}}$ & $6.10^{\star}$ \\
\hline$N(\%)$ & $0.35 \pm 0.03^{a}$ & $0.16 \pm 0.01^{\mathrm{b}}$ & $0.19 \pm 0.01^{b}$ & $18.93^{\star \star *}$ \\
\hline$C(\%)$ & $2.23 \pm 0.31^{a}$ & $1.97 \pm 0.16^{\mathrm{a}}$ & $2.17 \pm 0.05^{a}$ & 1.30 n.s. \\
\hline C:N ratio & $6.22 \pm 0.42^{\mathrm{a}}$ & $12.21 \pm 0.78^{b}$ & $11.4 \pm 0.42^{b}$ & $17.51^{\star \star \star}$ \\
\hline CEC $\left(\mathrm{cmol}^{\prime} \cdot \mathrm{kg}^{-1}\right)$ & $15.37 \pm 0.84^{\mathrm{a}}$ & $6.63 \pm 0.41^{b}$ & $8.49 \pm 0.48^{b}$ & $17.33^{\star * *}$ \\
\hline \multicolumn{5}{|l|}{ Vegetation } \\
\hline Total no. spp. & 59 & 69 & 93 & \\
\hline Mean no. spp. plot ${ }^{-1}$ & $13.8 \pm 0.4^{\mathrm{a}}$ & $23.3 \pm 0.3^{b}$ & $27.6 \pm 0.6^{b}$ & $17.58^{\star \star \star *}$ \\
\hline
\end{tabular}

\section{Soil seed bank survey}

Soil seed banks in renosterveld and abandoned fields were distinct, while the pine plantation's seed bank was more similar to renosterveld sites. With a depleted indigenous soil seed bank, abandoned fields are ostensibly unsuitable for restoration attempts that rely on viable seeds in the soil. In contrast, the pine plantation was more similar to renosterveld and had a viable indigenous soil seed bank. Although low replication is an unavoidable character of soil seed bank studies, due to the immense work load and logistics involved, we are still able to provide insights into soil seed banks of this endangered ecosystem.

Soils seed numbers in renosterveld and degraded sites were equally high $\left(4948-15634 \mathrm{~m}^{-2}, 4773-11530 \mathrm{~m}^{-2}\right.$, respectively). A similar magnitude was previously found for pristine renosterveld $\left(16429 \mathrm{~m}^{-2}\right)$ and abandoned fields (11 714-121 $600 \mathrm{~m}^{-2}$; N.N. Shiponeni unpubl. data). However, considerably lower seed numbers have been found in pristine (1100-1900 $\left.\mathrm{m}^{-2}\right)$ and invaded $\left(1200-1300 \mathrm{~m}^{-2}\right)$ mountain fynbos vegetation (1100$1900 \mathrm{~m}^{-2}$; Holmes \& Cowling 1997), as well as in sand plain fynbos vegetation (Holmes 2002a). Soil seed banks in other mediterranean-type vegetation types (Parker et al. 1989) are also of lower magnitude, as shown for Chilean matoral (pristine vegetation 293-1050 $\mathrm{m}^{-2}$, abandoned fields 325-678 m²; Jiménez \& Armesto 1992). Data indicate that renosterveld hosts a higher number of soil seeds compared to other mediterranean vegetation types.

Higher seed densities were generally found in the upper soil layers, as also reported from fynbos vegetation (Holmes 2002a). However, at one site, there was an even distribution of seed numbers between the upper and lower soil layers, possibly due to high bioturbation by fossorial diggers, such as mole rats, at this site (pers. obs.). Differences in seed abundance between soil layers are caused by seed migration through dislocation or underground living organisms (Baskin \& Baskin 1989). Although fossorial diggers have frequently been reported to disrupt restoration efforts, one positive influence is that seeds that have arrived in deeper soil layers have a higher potential for persistence in the long term (Bakker et al. 1996), once stressors have been removed.

\section{Influence of smoke primer}

Although more seedlings appeared after smoke treatment, this was only significant for certain renosterveld sites. Thirteen species, three of them alien, showed a significantly higher germination response after smoke-primer treatment. While Fynbos species show a clear germination response to smoke extract (Brown et al. 2003), a relatively low fire response has been reported for species from the Mediterranean Basin (Crosti et al. 2006). Our results are consistent with the few fire studies reported from abandoned fields in renosterveld. Here, the total species number did not increase after burn but species composition changed (Memiaghe, unpubl. data). Minor fire effects on species number were also observed compared to other restoration treatments (Musil et al. 2005; Midoko-Iponga unpubl. data). A variety of reasons could explain the relatively low smoke primer response for renosterveld. First of all, the low germination magnitude might be due to suboptimal smoke primer concentration. While low smoke concentrations can enhance germination, germination inhibition is reported for high concentrations (PérezFernández \& Rodríguez-Echeverría 2003). Second, renosterveld species could be more affected by heat than smoke. Such independent fire responses have been reported for other mediterranean-type ecosystems 


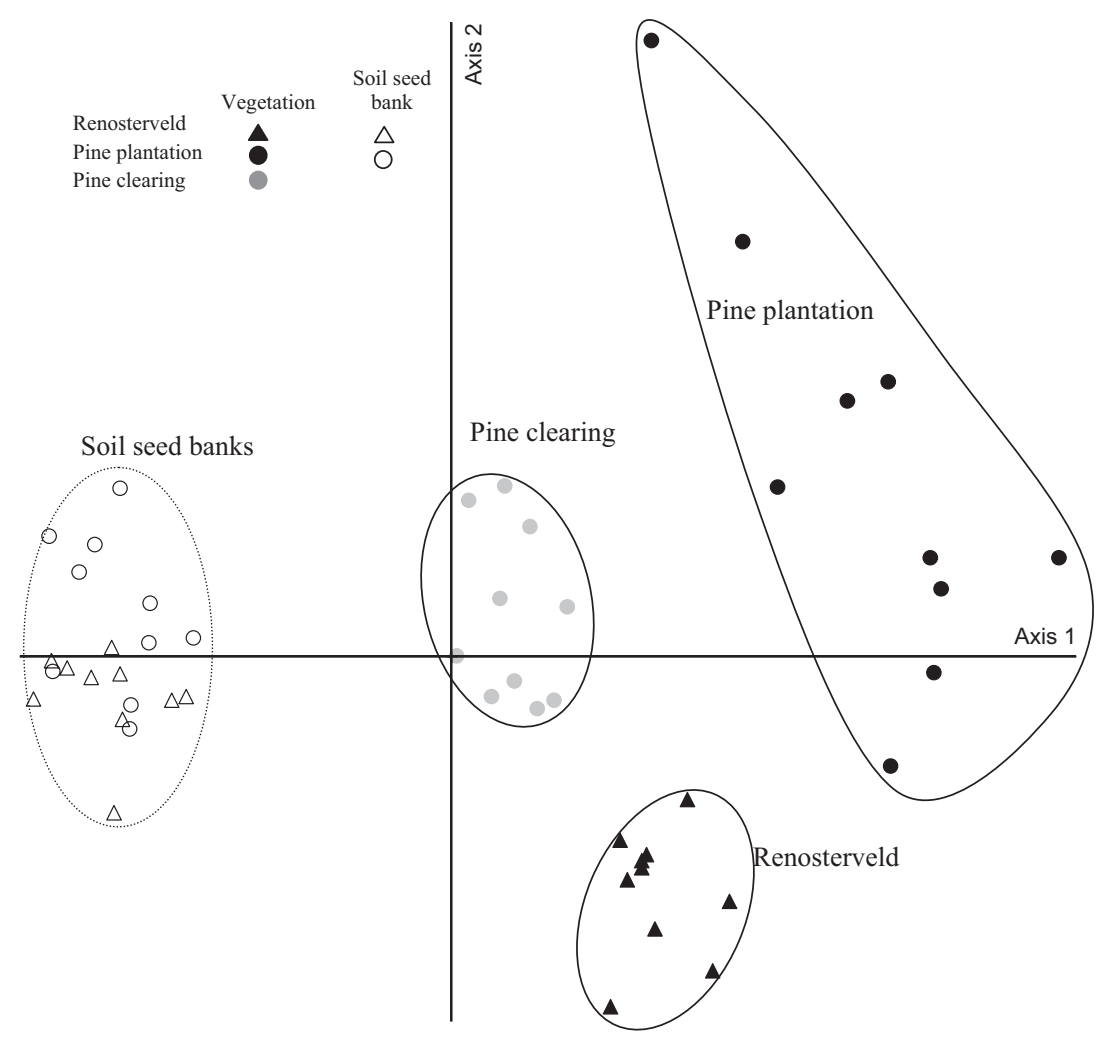

Fig. 3. DCA analysis of vegetation and soil seed bank at clear-cut experiment. Power-transformed matrix of 173 taxa and 50 plots. Vegetation of pine plantation (black circles), pine clearing (grey circles), renosterveld (black triangles), soil seed bank of renosterveld (empty triangles) and pine plantation (empty circles). Increment (axis 1: 0.51, axis 2: 0.09, length of gradient: 0.44 ).

(Enright et al. 1997). Recent research shows that both heat and smoke are important germination cues in Mediterranean Basin plant species (Moreira et al. 2010). It is also possible that smoke primer is not as effective as aerosol smoke (Roche et al. 1997). Finally, renosterveld species may indeed be more prone to other disturbances than to fire (cf. Keeley 1995). This is supported by research that questioned the universal germination enhancing effect of fire (Pierce et al. 1995). Renosterveld has more fertile soil and palatable vegetation than fynbos and once supported large herds of game (Krug \& Krug 2007). These drivers could have led to disturbance adaptation rather than to pronounced fire and/or smoke response.

From a restoration and conservation perspective, however, results would still support strategies that involve fire for renosterveld management. Fire is a valuable tool to enhance species diversity and abundance, even if the magnitude is much lower compared to fynbos. However, caution is needed in renosterveld habitats with high alien species presence. This is especially true for degraded sites, such as abandoned fields. Removing alien grasses can be followed by appearance of more noxious species from the soil seed bank (Mau-Crimmins 2007), such as Echium plantagineum, which can dominate disturbed parts of this landscape. This dilemma can only be avoided by conducting vegetation and soil seed bank surveys prior to fire management interventions.

\section{Comparison of vegetation data and soil seed bank}

Above-ground renosterveld and pine clear-cut vegetation differed greatly from below-ground soil seed banks. Low similarity of above- and below-ground vegetation is a well-known phenomenon found in stable (Thompson 2000) and successional plant communities (Livingston $\delta$ Allessio 1968). Therefore, the soil seed bank of the pine plantation could still be viable after anthropogenic landuse change. Low species similarity is also reported from other vegetation types, depending on time since abandonment and management (Kalamees \& Zobel 1998). On the other hand, vegetation and soil seed banks of abandoned fields were very similar, suggesting that the seed bank was derived mainly from the recent seed rain. Such a pattern is also reported for abandoned fields in New York (Beatty 1991) and western Estonia (Kalamees \& Zobel 1998).

Results therefore indicate a relatively low restoration potential for abandoned fields but a high recovery 
potential for pine plantation, if reliance on the soil seed bank is the only restoration option. Therefore, priority for restoration should be given to clear-cut of pine stands, with their viable and valuable remnant soil seed banks. High variability in species composition and soil reflects heterogeneity in renosterveld, even in the relatively small location of the Tygerberg. Environmental variation could influence interpretation of site comparison.

\section{Restoration experiment}

Recent restoration attempts in abandoned fields have been largely unsuccessful or expensive (Holmes 2002b; Krug \& Krug 2007), despite their promising potential and pre-testing of effectiveness (Heelemann et al. 2012). Therefore, pilot studies are strongly recommended on-site, before launching large-scale restoration initiatives. In contrast, the restoration experiment in a pine plantation using a 'cut, remove, burn' technique was followed by good recovery of indigenous flora and alignment of soil parameters similar to renosterveld. Soil seed banks of renosterveld and pine clear-cut sites were very similar. Pine plantations appear to preserve species from the indigenous renosterveld species pool, which could be activated after pine clearing.

Pine plantations are widespread on the landscape and present severe ecological, philosophical and policy challenges (Lindenmayer et al. 2008; van Wilgen \& Richardson 2012). Pinus spp. are highly invasive, especially in the southern hemisphere (Richardson et al. 1994), and due to comparatively nutrient-rich soils, renosterveld is very susceptible to invasion by this species. Clearing is an appropriate tool to avoid further spread by eliminating the seed source and simultaneously creating new renosterveld habitats (Boucher 1984). Although a high level of habitat degradation can reduce the suitability for re-establishment of species once present (Miller \& Hobbs 2007), pine plantations do have a high restoration value, due to the retention of a viable native soil seed bank (Kiefer \& Poschlod 1996). However, seed dispersal from adjacent natural sites into restoration sites is also important (Poschlod et al. 1998; Bisteau \& Mahy 2005). For example, pine clearing in fynbos results in good recovery of indigenous species (Holmes et al. 2000; Holmes 2001; Petersen et al. 2007) and is also suggested for renosterveld (De Villiers et al. 2005). Apart from an unpublished observation of renosterveld recovery after pine clearing at Papegaaiberg near Stellenbosch (C. Boucher, pers. comm.), our results from the Tygerberg provide the first published study. Here, removal of the largest cut logs and burning of small fuel loads resulted in recovery of soil parameters and indigenous flora. This is a validation for the information found in the fynbos ecosystem guidelines (De Villiers et al. 2005).
In fynbos, 'clearing and burning' of cut exotics has a greater impact on species richness than the 'burn standing, cut, remove' approach, although managers often have few options (Britton \& Jackelman 1995; Holmes et al. 2000; Cilliers et al. 2004). The 'cut, remove, burn' technique used in this study can offset cutting cost due to subsequent removal of wood by contractors. Furthermore, removal of logs reduces fuel loads and lowers fire intensities.

Vast pine populations are currently present in the Western Cape, especially at Tygerberg and Bottelary Hills. Estimations of $23 \mathrm{~km}^{2}$ by Kruger (1982) are the only existing data on the actual extent of pine-infested area in renosterveld. However, rates of spread models (Rouget et al. 2004) suggest that this area is likely to be more extensive today. Future research needs to measure the extent of pineinfested area in renosterveld and fynbos, using remote sensing and GIS technology, in order to pinpoint and prioritize suitable restoration areas.

\section{Acknowledgements}

We would like to thank the following for their invaluable support: Tygerberg Nature Reserve, Friends of the Tygerberg, Jaques Kuyler, Jurg Zimmermann, Verena Busch, Sara Wennige, Barbara Hinterschwepfinger, Raphael Kongor and Anne Horn. The project was funded by the German Federal Ministry of Education and Research (promotion number 01LC0624C).

\section{References}

Bakker, J.P. \& Berendse, F. 1999. Constraints in the restoration of ecological diversity in grassland and heathland communities. Trends in Ecology e Evolution 14: 63-68.

Bakker, J.P., Poschlod, P., Strykstra, R.J., Bekker, R.M. \& Thomson, K. 1996. Seed banks and seed dispersal: important topics in restoration ecology. Acta Botanica Neerlandica 45: 461-490.

Baskin, C. \& Baskin, J. 1989. Physiology of dormancy and germination in relation to seed bank ecology. In: Leck, M.A., Parker, V.T. \& Simpson, R.L. (eds.) Ecology of soil seed banks, pp. 53-66. Academic Press, San Diego, CA, US.

Baskin, J.M., Baskin, C.C. \& Li, X. 2000. Taxonomy, anatomy and evolution of physical dormancy in seeds. Plant Species Biology 15: 139-152.

Bassett, I.E., Simcock, R.C. \& Mitchell, N.D. 2005. Consequences of soil compaction for seedling establishment: implications for natural regeneration and restoration. Austral Ecology 30: 827-833.

Beatty, S.W. 1991. Colonization dynamics in a mosaic landscape: the buried seed pool. Journal of Biogeography 18: 553-563.

Bisteau, E. \& Mahy, G. 2005. Vegetation and seed bank in a calcareous grassland restored from a Pinus forest. Applied Vegetation Science 8: 167-174. 
Boucher, C. 1984. Patterns of invasion by larger woody alien species in selected areas of the fynbos biome, South Africa. In: Dell, B. (ed.) Proceedings of the Fourth International Conference on Mediterranean Ecosystems, pp. 12-13. University of Western Australia, Nedlands. Invasive plants.

Braun-Blanquet, J. 1964. Pflanzensoziologie: Grundzüge der Vegetationskunde. Springer, Vienna, AT.

Britton, P \& Jackelman, J 1995. Biological management of renosterveld: some questions and lessons from Signal Hill and Devil's Peak, in the sustainable use and management of renosterveld remnants in the Cape Floristic Region. In: Low, A.B. \& Jones, F.E. (eds.) Proceedings of a symposium. FCC 1995/ 4, pp. 58-62. Flora Conservation Commitee, Botanical Society of South Africa, Kirstenbosch, Cape Town.

Brown, N.A.C. 1993. Promotion of germination of fynbos seeds by plant-derived smoke. New Phytologist 123: 575-583.

Brown, N.A.C. \& Botha, P.A. 2004. Smoke seed germination studies and a guide to seed propagation of plants from the major families of the Cape Floristic Region, South Africa. South African Journal of Botany 70: 559-581.

Brown, N.A.C., Botha, P.A. \& Kotze, G. 1993. The promotion of seed germination of Cape Erica species by plant-derived smoke. Seed Science and Technology 21: 573-580.

Brown, N.A.C., van Staden, J., Daws, M.I. \& Johnson, T. 2003. Patterns in the seed germination response to smoke in plants from the Cape Floristic Region, South Africa. South African Journal of Botany 69: 514-525.

Caldwell, M.M., Richards, J.H., Manwaring, J.H. \& Eissenstat, D.M. 1987. Rapid shifts in phosphate acquisition show direct competition between neighbouring plants. Nature 327: 615616.

Cilliers, C.D., Esler, K. \& Boucher, C. 2004. Effects of alien plant management and fire on soil seed banks and regeneration in the Cape Peninsula National Park, South Africa. South African Journal of Botany 70: 705-712.

Cramer, V.A. \& Hobbs, R.J. 2007. Old fields: dynamics and restoration of abandoned farmland. Island Press, Washington, DC, US.

Crosti, R., Ladd, P.G., Dixon, K.W. \& Piotto, B. 2006. Post-fire germination: the effect of smoke on seeds of selected species from the central Mediterranean basin. Forest Ecology and Management 221: 306-312.

Davies, R.J. 1985. The importance of weed control and the use of tree shelters for establishing broadleaved trees on grass-dominated sites in England. Forestry 58: 167-180.

De Lange, J.H. \& Boucher, C. 1990. Autecological studies on Audouinia capitata (Bruniaceae). I. Plant-derived smoke as a seed germination cue. South African Journal of Botany 56: 700-703.

De Villiers, C.C., Driver, A., Clark, B., Euston-Brown, D.I.W., Day, E.G., Job, N., Helme, N.A., Holmes, P.M., Brownlie, S. \& Rebelo, A.B. 2005. Fynbos Forum ecosystem guidelines for environmental assessment in the Western Cape. Fynbos Forum. Botanical Society of South Africa, Conservation Unit, Kistenbosch, Cape Town, ZA.
Dixon, K., Merritt, D., Flematti, G. \& Ghisalberti, E. 2009. Karrikinolide - a phytoreactive compound derived from smoke with applications in horticulture, ecological restoration and agriculture. Acta Horticulturae 813: 155-170.

Eliason, S.A. \& Allen, E.B. 1997. Exotic grass competition in suppressing native shrubland re-establishment. Restoration Ecology 5: 245-255.

Enright, N., Goldblum, D., Ata, P. \& Ashton, D. 1997. The independent effects of heat, smoke and ash on emergence of seedlings from the soil seed bank of a heathy Eucalyptus woodland in Grampians (Gariwerd) National Park, western Victoria. Austral Ecology 22: 81-88.

Flematti, G.R., Ghisalberti, E.L., Dixon, K.W. \& Trengove, R.D. 2004. A compound from smoke that promotes seed germination. Science 305: 977.

Flematti, G.R., Merritt, D.J., Piggott, M.J., Trengove, R.D., Smith, S.M., Dixon, K.W. \& Ghisalberti, E.L. 2011. Burning vegetation produces cyanohydrins that liberate cyanide and stimulate seed germination. Nature Communications 2: article 360.

Fourie, S 2008. Composition of the soil seed bank in alieninvaded grassy fynbos: potential for recovery after clearing. South African Journal of Botany 74: 445-453.

Goldblatt, P \& Manning, J 2000. Cape plants: a conspectus of the Cape flora of South Africa. National Botanical Institute, Cape Town \& Missouri Botanical Garden, St. Louis.

Heelemann, S., Krug, C.B., Esler, K.J., Reisch, C. \& Poschlod, P. 2012. Pioneers and perches - promising restoration methods for degraded renosterveld habitats? Restoration Ecology 20: $18-23$.

Holmes, P.M. 2001. Shrubland, restoration following woody alien invasion and mining: effects of topsoil depth, seed source, and fertilizer addition. Restoration Ecology 9: 71.

Holmes, P.M. 2002a. Depth distribution and composition of seed-banks in alien-invaded and uninvaded fynbos vegetation. Austral Ecology 27: 110-120.

Holmes, P.M. 2002b. Renosterveld restoration on cultivated lands at Eerste River, Western Cape: preliminary findings of a pilot study. Cape Ecological Services, Bergvliet, ZA.

Holmes, P.M. 2005. Results of a lucerne old-field restoration experiment at the Fynbos-Karoo interface. South African Journal of Botany 71: 326-338.

Holmes, P.M. 2008. Optimal ground preparation treatments for restoring lowland Sand Fynbos vegetation on old fields. South African Journal of Botany 74: 33-40.

Holmes, P.M. \& Cowling, R.M. 1997. Diversity, composition and guild structure relationships between soil-stored seed banks and mature vegetation in alien plant-invaded South African fynbos shrublands. Plant Ecology 133: 107-122.

Holmes, P.M. \& Richardson, D.M. 1999. Protocols for restoration based on recruitment dynamics, community structure, and ecosystem function: perspectives from South African fynbos. Restoration Ecology 7: 215-230.

Holmes, P.M., Richardson, D.M., van Wilgen, B.W. \& Gelderblom, C. 2000. Recovery of South African fynbos vegetation 
following alien woody plant clearing and fire: implications for restoration. Austral Ecology 25: 631-639.

Horn, A., Krug, C.B., Newton, I.P. \& Esler, K.J. 2011 . Specific edge effects in highly endangered Swartland Shale Renosterveld in the Cape Region. Ecologia Mediterranea 37: 63-74.

Jiménez, H.E. \& Armesto, J.J. 1992. Importance of the soil seed bank of disturbed sites in Chilean matorral in early secondary succession. Journal of Vegetation Science 3: 579-586.

Jones, F. \& Esler, K. 2004. Relationship between soil-stored seed banks and degradation in eastern Nama Karoo rangelands (South Africa). Biodiversity and Conservation 13: 2027-2053.

Kalamees, R. \& Zobel, M. 1998. Soil seed bank composition in different successional stages of a species-rich wooded meadow in Laelatu, western Estonia. Acta Oecologica 19: 175180.

Keeley, J.E. 1995. Seed germination patterns in fire-prone Mediterranean climate regions. In: Arroyo, M.T.K., Zedler, P.H. \& Fox, M.D. (eds.) Ecology and biogeography of Mediterranean ecosystems in Chile, California, and Australia, pp. 239-273. Springer, New York, NY, US.

Kemper, J., Cowling, R.M. \& Richardson, D.M. 1999. Fragmentation of South African renosterveld shrublands: effects on plant community structure and conservation implications. Biological Conservation 90: 103-111.

Kiefer, S. \& Poschlod, P. 1996. Restoration of fallow or afforested calcareous grasslands by clear-cutting. In: Settele, J., Margules, C., Poschlod, P. \& Henle, K. (eds.) Species survival in fragmented landscapes, pp. 209-218. Kluwer, Dordrecht, NL.

Krug, C.B. \& Krug, R.M. 2007. Restoration in old fields in renosterveld: a case study in a Mediterranean-type shrubland of South Africa. In: Cramer, V.A. \& Hobbs, R.J. (eds.) Old fields: dynamics and restoration of abandoned farmland, pp. 265-285. Island Press, Washington DC, US.

Kruger, F.J. 1982. Use and management of Mediterranean Ecosystems in South Africa - current problems. In: Conrad, C.E. $\&$ Oechel, W.C. (eds.) Proceedings of the symposium on dynamics and management of Mediterranean-type ecosystems, pp. 42-55. Pacific Southwest Forest and Range Experiment Station, San Diego, CA, US.

Kruger, F., Breitenbach, G., MacDonald, I. \& Richardson, D. 1989. The characteristics of invaded Mediterranean-climate regions. In: Drake, J., Mooney, H., di Castri, F., Groves, R., Kruger, F., Rejmnanek, M. \& Williamson, M. (eds.) Biological invasions: a global perspective, pp. 181-213. Wiley, Chichester, UK.

Lambrechts, J.J.N. 1998. Natural resources and farming in the Tygerberg. In: Du Plessis, N.M. (ed.) The Tygerberg: the story of Tygerberg Hills and the towns of Parow, pp. 112-126. Bellville and Durbanville, Tafelberg, Cape Town, ZA.

Leishman, M.R. \& Thomson, V.P. 2005. Experimental evidence for the effects of additional water, nutrients and physical disturbance on invasive plants in low fertility Hawkesbury Sandstone soils, Sydney, Australia. Journal of Ecology 93: 38-49.

Lindenmayer, D.B., Fischer, J., Felton, A., Crane, M., Michael, D., Macgregor, C., Montague-Drake, R., Manning, A.,
Hobbs, R.J. \& Bradshaw, C. 2008. Novel ecosystems resulting from landscape transformation create dilemmas for modern conservation practice. Conservation Letters 1: 129-135.

Livingston, R.B. \& Allessio, M.L. 1968. Buried viable seed in successional field and forest stands, Harvard Forest, Massachusetts. Bulletin of the Torrey Botanical Club 95: 58-69.

Mau-Crimmins, T. 2007. Effects of removing Cynodon dactylon from a recently abandoned agricultural field. Weed Research 47: 212-221.

Midoko-Iponga, D., Krug, C.B. \& Milton, S.J. 2005. Competition and herbivory influence growth and survival of shrubs on old fields: implications for restoration of renosterveld shrubland. Journal of Vegetation Science 16: 658-692.

Miller, J.R. \& Hobbs, R.J. 2007. Habitat restoration - do we know what were doing? Restoration Ecology 15: 382-390.

Moreira, B., Tormo, J., Estrelles, E. \& Pausas, J. 2010. Disentangling the role of heat and smoke as germination cues in Mediterranean Basin flora. Annals of Botany 105: 627-635.

Musil, C.F., Milton, S.J. \& Davis, G.W. 2005. The threat of alien invasive grasses to lowland Cape floral diversity: an empirical appraisal of the effectiveness of practical control strategies. South African Journal of Science 101: 337-344.

Myers, N., Mittermeier, R.A., Mittermeier, C.G., da Fonseca, G.A.B. \& Kent, J. 2000. Biodiversity hotspots for conservation priorities. Nature 403: 853-858.

Newton, I.P. \& Knight, R.S. 2005. The use of a 60-year series of aerial photographs to assess local agricultural transformations of West Coast Renosterveld, an endangered South African vegetation type. South African Geographical Journal 87: 18-27.

O'Farrell, P.J. \& Collard, S. 2003. Ecosystem services: an examination of approaches to investigating ecosystem services in agricultural landscapes in South Africa and Australia. In: Allsopp, N., Palmer, A.R., Milton, S., Kirkman, K.P., Kerley, G.I.H., Hurt, C.R. \& Brown, C.J. (eds.) VIIth International Rangelands Congress, pp. 1513-1514. Document Transformation Technologies, Durban, ZA.

O'Farrell, P.J., Donaldson, J.S. \& Hoffman, M.T. 2009. Local benefits of retaining natural vegetation for soil retention and hydrological services. South African Journal of Botany 75: 573583.

Parker, V.T., Kelly, V.R., Leck, M.A., Parker, V.T. \& Simpson, R.L. 1989. Seed banks in California chaparral and other Mediterranean climate shrublands. In: Leck, M., Parker, V. \& Simpson, R. (eds.) Ecology of soil seed banks, pp. 236-256. Academic Press, San Diego, CA, US.

Pérez-Fernández, M.A. \& Rodríguez-Echeverría, S. 2003. Effect of smoke, charred wood, and nitrogenous compounds on seed germination of ten species from woodland in CentralWestern Spain. Journal of Chemical Ecology 29: 237-251.

Petersen, N., Husted, L., Rebelo, T. \& Holmes, P. 2007. Fynbos wake up call: restoration of Sand Fynbos in Tokai. Veld $\theta$ Flora 93: 102.

Pierce, S.M., Esler, K. \& Cowling, R.M. 1995. Smoke-induced germination of succulents (Mesembryanthemaceae) from 
fire-prone and fire-free habitats in South Africa. Oecologia 102: 520-522.

Poschlod, P., Kiefer, S., Tränkle, U., Fischer, S. \& Bonn, S. 1998. Plant species richness in calcareous grasslands is effected by dispersibility in space and time. Applied Vegetation Science 1: 75-90.

Rebelo, A.G., Boucher, C., Helme, N., Mucina, L., Rutherford, M.C., Smit, W.J., Powrie, L.W., Ellis, F., Lambrechts, J.J. \& Scott, L. 2006. Fynbos biome. In: Mucina, L. \& Rutherford, M.C. (eds.) The vegetation of South Africa. Lesotho and Swaziland, pp. 53-219. South African National Biodiversity Institute, Pretoria, ZA.

Richardson, D.M., Williams, P.A. \& Hobbs, R.J. 1994. Pine invasions in the Southern Hemisphere: determinants of spread and invadability. Journal of Biogeography 21: 511-527.

Roche, S., Koch, J.M. \& Dixon, K.W. 1997. Smoke enhanced seed germination for mine rehabilitation in the southwest of Western Australia. Restoration Ecology 5: 191-203.

Rouget, M., Richardson, D.M., Milton, S.J. \& Polakow, D. 2004. Predicting invasion dynamics of four alien Pinus species in a highly fragmented semi-arid shrubland in South Africa. Plant Ecology 152: 79-92.

Saayman, N. \& Botha, J.C. 2008. Does the soil seed bank of veld dominated by Pteronia paniculata change as a result of brushcutting? Grassroots: Newsletter of the Grassland Society of Southern Africa 8: 32-35.

Saunders, D.A., Hobbs, R.J. \& Margules, C.R. 1991. Biological consequences of ecosystem fragmentation: a review. Conservation Biology 5: 18-32.

Schlichting, E. \& Blume, H.P. 1966. Bodenkundliches Praktikum. Parey, Berlin, DE.
Sharma, G.P., Muhl, S.A., Esler, K.J. \& Milton, S.J. 2010. Competitive interactions between the alien invasive annual grass Avena fatua and indigenous herbaceous plants in South African Renosterveld: the role of nitrogen enrichment. Biological Invasions 12: 3371-3378.

Suding, K.N., LeJeune, K.D. \& Seastedt, T.R. 2004. Competitive impacts and responses of an invasive weed: dependencies on nitrogen and phosphorus availability. Oecologia 141: 526535.

Ter Heerdt, G.N.J., Verweij, G.L., Bekker, R.M. \& Bakker, J.P. 1996. An improved method for seed-bank analysis: seedling emergence after removing the soil by sieving. Functional Ecology 10: 144-151.

Thompson, K. 2000. The functional ecology of soil seed banks. In: Fenner, M. (ed.) Seeds: the ecology of regeneration in plant communities, pp. 215-235. CABI, Wallingford, UK.

Van Staden, J., Jäger, A.K., Light, M.E. \& Burger, B.V. 2004. Isolation of the major germination cue from plant-derived smoke. South African Journal of Botany 70: 654-659.

von Hase, A., Rouget, M., Maze, K. \& Helme, N.A. 2003. A finescale conservation plan for Cape Lowlands Renosterveld. Summary report. Conservation Unit, Botanical Society of SA, Cape Town, ZA.

van Wilgen, B.W. 2009. The evolution of fire and invasive alien plant management practices in fynbos. South African Journal of Science 105: 335-342.

van Wilgen, B.W. \& Richardson, D.M. 2012. Three centuries of managing introduced conifers in South Africa: benefits, impacts, changing perceptions and conflict resolution. Journal of Environmental Management 106: 56-68. 